\title{
The allometric model in the stand density management of Pinus pinaster Ait. in Portugal
}

\author{
Jaime F. SALES LUIS*, Teresa F. FONSECA \\ Departamento Florestal, Universidade de Trás-os-Montes e Alto Douro, 5000 Vila Real, Portugal
}

(Received 16 July 2003; accepted 17 June 2004)

\begin{abstract}
The allometric model is very suitable for practical applications, as it gives an approximately correct expression of a number of relations, such as plant density $(N)$ and average plant size $(d g)$, very useful in forest management. Density management diagrams, based on the allometric model, are simple and effective procedures to display the complex dimensional stand development relationships and to translate general management objectives into stand-specific thinning prescriptions. This study presents a comprehensive approach, based on the allometric model, to manage the development of Pinus pinaster even-aged stands in Portugal, using National Forest Inventory data of 1998. The self-thinning allometric model is a linear limiting relationship, between $N$ and $d g$. It requires upper boundary plot selection and corresponds to the use of the upper confidence interval limit for the intercept coefficient (13.634), with a slope coefficient of -1.897 . The upper and lower limits for the optimum growth-density interval also requires attention. In this study, trees square spacing and a $10 \mathrm{~cm}$ reference diameter were selected to calculate limits that are, respectively, 63\% and 32\%. Two associated relationships (dominant height and total volume isolines) were developed to allow evaluation of thinning regimes in terms of age, height and volume. Three alternative management regimes (unthinned, commercial and precommercial), aiming a $30 \mathrm{~cm}$ target diameter, were discussed and compared. Mortality was only predicted in the unthinned regime, accounting for $46 \%$ total yield loss. The $30 \mathrm{~cm}$ target diameter was reached considerably earlier in the precommercial (38 years) and commercial (45 years) regimes, compared with the unthinned regime (54 years), but at the expense of a much lower residual trees.ha ${ }^{-1} 350$ 544 and 789 , yielding a total volume of 278,600 and $992 \mathrm{~m}^{3} \cdot \mathrm{ha}^{-1}$ and corresponding to $7.3,13.3$ and $18.4 \mathrm{~m}^{3} \cdot \mathrm{ha}^{-1} \cdot \mathrm{yr}^{-1} \mathrm{MAI}$, respectively.
\end{abstract}

Pinus pinaster / allometric model / stand density management

Résumé - Modèle allométrique pour la gestion de la densité des peuplements de Pinus pinaster Ait., au Portugal. Le modèle allométrique est très convenable pour des applications pratiques, car il donne une expression quasiment correcte d'un nombre de relations, tels que la densité des plants $(N)$ et la dimension moyenne des plants $(d g)$, très utiles dans l'aménagement forestier. Les diagrammes de gestion de la densité sont une procédure simple et efficace pour présenter les relations dimensionnelles complexes du développement des peuplements et de traduire les objectifs généraux de gestion dans des règles d'éclaircies spécifiques au peuplement. Cette étude présente une approche globale, basée sur un modèle allométrique, pour la gestion des peuplements réguliers de Pinus pinaster au Portugal, utilisant les données de l'Inventaire Forestier National de 1998. Le modèle allométrique d'auto-régulation est une relation linéaire limite, entre $N$ et $d \mathrm{~g}$. Son calcul demande la sélection des données de la limite supérieure et correspond à l'usage de la limite supérieure de l'intervalle de confiance pour le coefficient d'interception de l'espèce $(13,634)$, avec un coefficient de pente de $-1,897$. Les limites supérieure et inférieure de l'intervalle optimal de croissance-densité demandent aussi une attention particulière. Dans cette étude l'espacement carré et le diamètre de référence de $10 \mathrm{~cm}$ ont été sélectionnés pour le calcul de ces limites, respectivement, $63 \%$ et $32 \%$. Deux relations associées (isolignes hauteur dominante et volume) sont développées pour permettre une évaluation précise des régimes d'éclaircie concernant l'âge, la hauteur et le volume. Trois différents régimes de sylviculture (sans éclaircies, éclaircies commerciales et précommerciales), visant un diamètre objectif de $30 \mathrm{~cm}$, sont discutés et comparés. La mortalité est seulement observée dans le régime sans éclaircies, occasionnant une perte totale de production de $46 \%$. Le diamètre objectif de $30 \mathrm{~cm}$ est obtenu relativement tôt dans les régimes d'éclaircies précommerciales (38 années) et commerciales (45 années), comparés avec le régime sans éclaircies (54 années) mais aux dépens d'un nombre d'arbres à l'ha résiduels plus réduit, respectivement 350, 544 et 789, produisant un volume total de 278,600 et $992 \mathrm{~m}^{3} \cdot \mathrm{ha}^{-1}$ et correspondant à 7,3, 13,3 et $18,4 \mathrm{~m}^{3} \cdot \mathrm{ha}^{-1} \cdot \mathrm{yr}^{-1}$ du AMA respectivement.

Pinus pinaster / modèle allométrique / gestion de la densité des peuplements

\section{INTRODUCTION}

Most animal and vegetal living matter exists in the form of discrete individuals for which general description depends on two fundamental entities: their number per unit area and their mass. Each of these entities belongs to one of the main branches of ecology, respectively, population ecology and production ecology [14]. The relationship between these variables linking together the two branches, belongs to neither of them; it constitutes the core of ecology [43].

\footnotetext{
* Corresponding author: jfsl@utad.pt
} 
It is widely accepted $[2,14,16,20,34,37-39]$ that in the evolution of monospecific even-aged populations of plants experiencing complete crown closure, mortality is densitydependent and is ruled by "the $3 / 2$ power law of self-thinning" formulated by Yoda et al. [43]. The law, also known as selfthinning rule, is described [4] by the allometric model between plant density $(N)$ and average plant size $(d g)$ :

$$
(d N / d t) / N=\mathrm{b}(d d g / d t) / d g
$$

in which the relative rate of $N$ growth is reciprocal to the relative rate of $d g$ growth. Integrating both sides yielded:

$$
N=\mathrm{a} d g^{\mathrm{b}} .
$$

The allometric model is very suitable for practical applications, as it gives an approximately correct expression of a number of relations [32]. For example, Reineke [33] derived the following model for different species growing in the United States west coast conditions:

$$
\log N=\mathrm{a}-1.605 \log d g .
$$

Oliveira [28], Gadow [15], McCarter and Long [23], Luis et al. [22], Dean and Baldwin [5], Kumar et al. [18] and Cao et al. [3], among others, have used this model for species growing in different environmental conditions and other slopes were found. Tolerant species tend to show a lower slope [44] and a higher intercept [14]. Wilson [40] and Drew and Flewelling [11] further developed this model, expressing the size variable by the top height and individual tree volume, respectively.

Stand development is a dynamic process in which growth, mortality and harvesting play an important role. Density management diagrams are a simple and effective means to display the complex dimensional stand development relationships and to translate general management objectives into stand-specific thinning prescriptions [27]. Their wide application is as a result of their utility in designing alternative management regimes, in displaying the results of stand density manipulation, and in translating general management objectives into practical thinning regimes [21].

For the genus Pinus, more than for any other genus, self-thinning allometric modelling $[1,3,15,28,29,33,38,42]$ and stand density diagrams $[5,6,10,12,22,23,41]$ have been developed.

Luis et al. [22] presented a preliminary study about the allometric model application for Pinus pinaster stands management in Portugal. In this paper, a comprehensive density management diagram is developed, using updated information, and its use is illustrated by examining three possible management regimes.

\section{MATERIALS AND METHODS}

\subsection{Data base}

In 1998, during the Portuguese National Forest Inventory, 501 circular sample plots were measured in pure Pinus pinaster stands [8]. These $500 \mathrm{~m}^{2}$ inventory plots were systematically scattered over the country $\left(36^{\circ} 57^{\prime \prime}\right.$ to $42^{\circ} 06^{\prime \prime} \mathrm{N}$ and $6^{\circ} 14^{\prime \prime}$ to $\left.9^{\circ} 32^{\prime \prime} \mathrm{W}\right)$ and different
Table I. Summary characteristics of the 274 inventory plots, used in this study.

\begin{tabular}{lcccc}
\hline $\begin{array}{l}\text { Stand } \\
\text { parameters }\end{array}$ & Minimum & Mean & Maximum & $\begin{array}{c}\text { Standard } \\
\text { deviation }\end{array}$ \\
\hline$t$ (years) & 7.0 & 38.0 & 80.0 & 17.0 \\
$h d(\mathrm{~m})$ & 3.2 & 14.6 & 29.8 & 6.2 \\
$d g(\mathrm{~cm})$ & 3.3 & 19.7 & 51.0 & 9.6 \\
$N\left(\mathrm{trees}^{\mathrm{h}} \cdot \mathrm{ha}^{-1}\right)$ & 60.0 & 913.0 & 8480.0 & 1172.0 \\
$G\left(\mathrm{~m}^{2} \cdot \mathrm{ha}^{-1}\right)$ & 0.3 & 17.0 & 52.9 & 12.0 \\
$V\left(\mathrm{~m}^{3} \cdot \mathrm{ha}^{-1}\right)$ & 0.9 & 126.9 & 489.7 & 112.5 \\
\hline
\end{tabular}

measurements (tree diameter at breast height $(d b h)$, sample tree height ( $h$ ) and, dominant and dominated trees age) were made. The data file for the sample plots contains the following stand variables: age $(t)$; number of trees per ha $(N)$, basal area per ha $(G)$ and over bark total volume per ha $(V)$; dominant diameter $(d d)$ and dominant height $(h d)$. Quadratic mean diameter $(d g)$ was computed from $N$ and $G$.

From all the plots, 227 were discarded due to: lack of information related to dominant trees (54); indirect stand recovery (16); unevenaged stands (144), extreme low density (3) and inadequate measurements (9). The remaining 274 inventory plots were considered acceptable for use (Tab. I). From these, 25 upper boundary plots were identified, according to Keeney and Raiffa's [17] boundary point definition, based on the simplified dominance concept. This concept states that $z$ ' is a boundary point in relation to $z$ ', when the following conditions are simultaneously verified:

$$
\begin{array}{ll}
z_{\mathrm{i}} \geq z^{\prime}{ }_{i} & \text { for all } i \text { variables } \\
z_{i}>z_{i} & \text { at least for one } i \text { variable }
\end{array}
$$

where $i$ is $N$ and/or $d g$.

The 25 upper boundary plots were used for developing the selfthinning line. For the development of the associated relationships in the stand density diagram ( $V$ and $h d$ isolines) all 274 acceptable inventory plots were used.

\subsection{Model development}

Density-dependent mortality is caused by an increase in tree size. Crown width is the best predictor of tree number in closed stands, although it cannot be reliably measured due to irregular crown form and overlap. Therefore, it is natural to use $N$ as the dependent variable and $d g$ as the independent variable, since it adequately expresses tree size, it is closely related to the number of trees and crown width and is also easily accessible for measuring [44].

The exponential allometric model (Eq. (2)) can be easily linearized, using a logarithmic transformation:

$$
\ln N=\mathrm{a}+\mathrm{b} \ln d g .
$$

This model is an average limiting relationship between plant density and average plant size. Hence, after fitting, it should be moved up vertically to represent a real limiting line.

The stand density diagram is a density $(N)$ size $(d g)$ relationship, but other scales are possible, available and useful, such as, the $V$ and $h d$ isolines. The development of these associated relationships in the stand density diagram are based on empirical models $[5,18]$, perhaps including explicitly the fundamental relationships of forest production. 


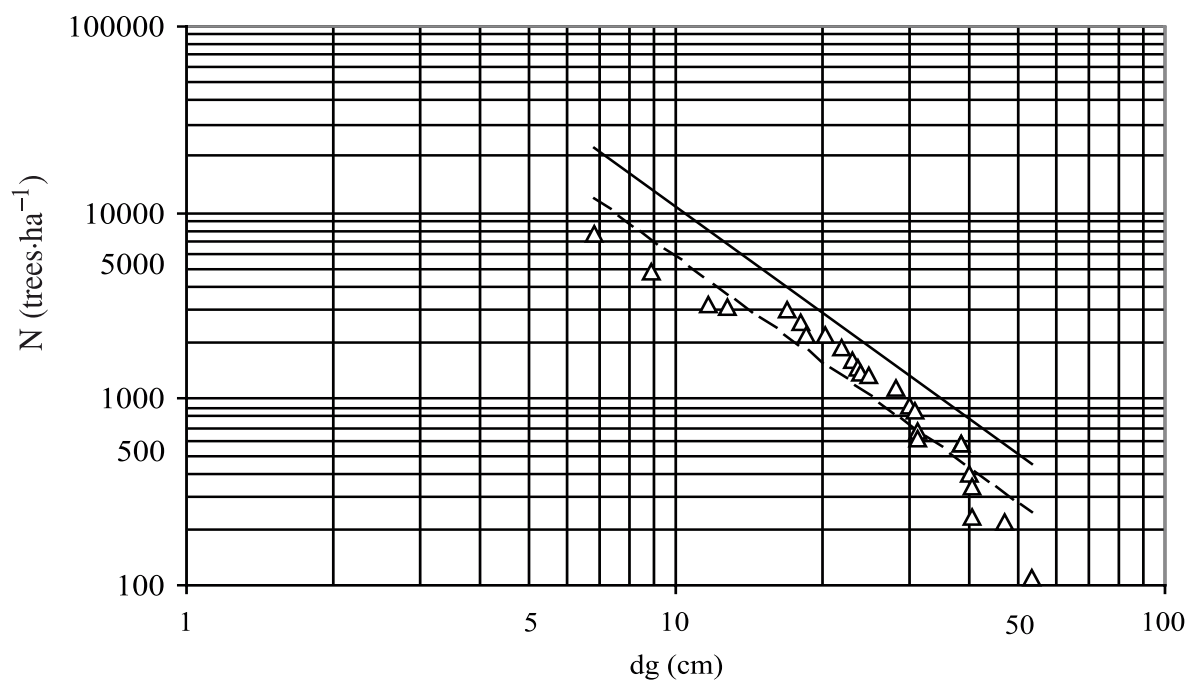

Figure 1. Plant density $(N)$ and average plant size $(d g)$ relationships. $\Delta$ boundary plots, - - - average line, ----- self-thinning line.

Dean and Baldwin [5], following McCarter and Long [23] approach, developed the models:

$$
\begin{gathered}
V=a_{1} d g^{a_{2}} N h d^{a_{3}} \\
d g=b_{1} V^{b_{2}} N^{b_{3}} .
\end{gathered}
$$

Combining equations (7) and (8), by the $V$ term and after algebraic manipulation yielded:

$$
h d=c_{1} d g^{c 2} N^{c 3}
$$

Kumar et al.'s [18] diagram isolines were obtained independently and rely on different conceptual models:

$$
\begin{gathered}
V=a_{1}+a_{2} N d g^{a_{3}} \\
d g=b_{1}+\left(b_{2}+b_{3} N^{b_{4}}\right) h d^{b_{5}} .
\end{gathered}
$$

Equations (7), (8), (10) and (11) were fitted and residual analysis was conducted to examine the model appropriateness. Model selection was based on the coefficient of determination $\left(r^{2}\right)$ and on the standard residual deviation $\left(s_{\mathrm{yx}}\right)$ criteria.

\section{RESULTS}

\subsection{Diagram construction}

Stand density diagram construction is a two step process. First, derive the self-thinning line and second, determine the limits for the optimum growth-density interval [19, 24] and for the crown closure line.

The application of the linearized allometric model (Eq. (6)) to the 25 boundary plots provided:

$$
\ln N=13.052-1.897 \ln d g
$$

with a $r^{2}$ of 0.897 and a $s_{y x}$ of 0.340 .
Equation (12) is an average relationship between plant density and average plant size. Fixing the upper limit for the intercept confidence interval at the $95 \%$ one tail level $[\alpha=0.05$; $\mathrm{t}(1-\alpha, \mathrm{n}-2 \mathrm{df})]$, we then obtained the limiting relationship between these variables or the self-thinning line we were looking for (Fig. 1):

$$
\ln N=13.634-1.897 \ln d g .
$$

The objectives for setting the upper and lower limits for the optimum growth-density interval are, respectively, avoiding density-related mortality and keeping the live-crown ratio above $40 \%$, the recommended minimum for good tree vigor [35], while maintaining adequate site occupancy [11]. These two limits for the optimum growth-density interval, along with the crown closure line, form three lower lines parallel to the selfthinning line.

In this study, square spacing of the trees was assumed and $10 \mathrm{~cm}$ was selected as the reference $d b h$ to compute the number of trees at different levels (Tab. II). The reference $d b h$ approximates the lower $d b h$ class in our data base and corresponds to the size for the first thinning operation in Pinus pinaster. Based on our experience with the species, at the reference $d b h$, the spacings $1.5 \times 1.0,2.0 \times 1.5$ and $2.0 \times 2.0 \mathrm{~m}$ approximate, respectively, the upper (6666) and lower (3333) limits for the optimum growth-density zone and to the crown closure (2500) situation (Tab. II). They are, respectively, 63.05, 31.53 and $23.64 \%$ of the $N$ maximum. Under these circumstances, we hypothesize that 60 and $35 \%$ are adequate values for the upper and lower limits of the optimum growth-density interval and $25 \%$ is the reasonable value for the crown closure situation, for Pinus pinaster in the Portuguese environment (Fig. 2). The equations for the three lower parallel lines are, respectively, the following:

$$
\begin{aligned}
& \ln N=13.123-1.897 \ln d g \\
& \ln N=12.584-1.897 \ln d g \\
& \ln N=12.248-1.897 \ln d g .
\end{aligned}
$$




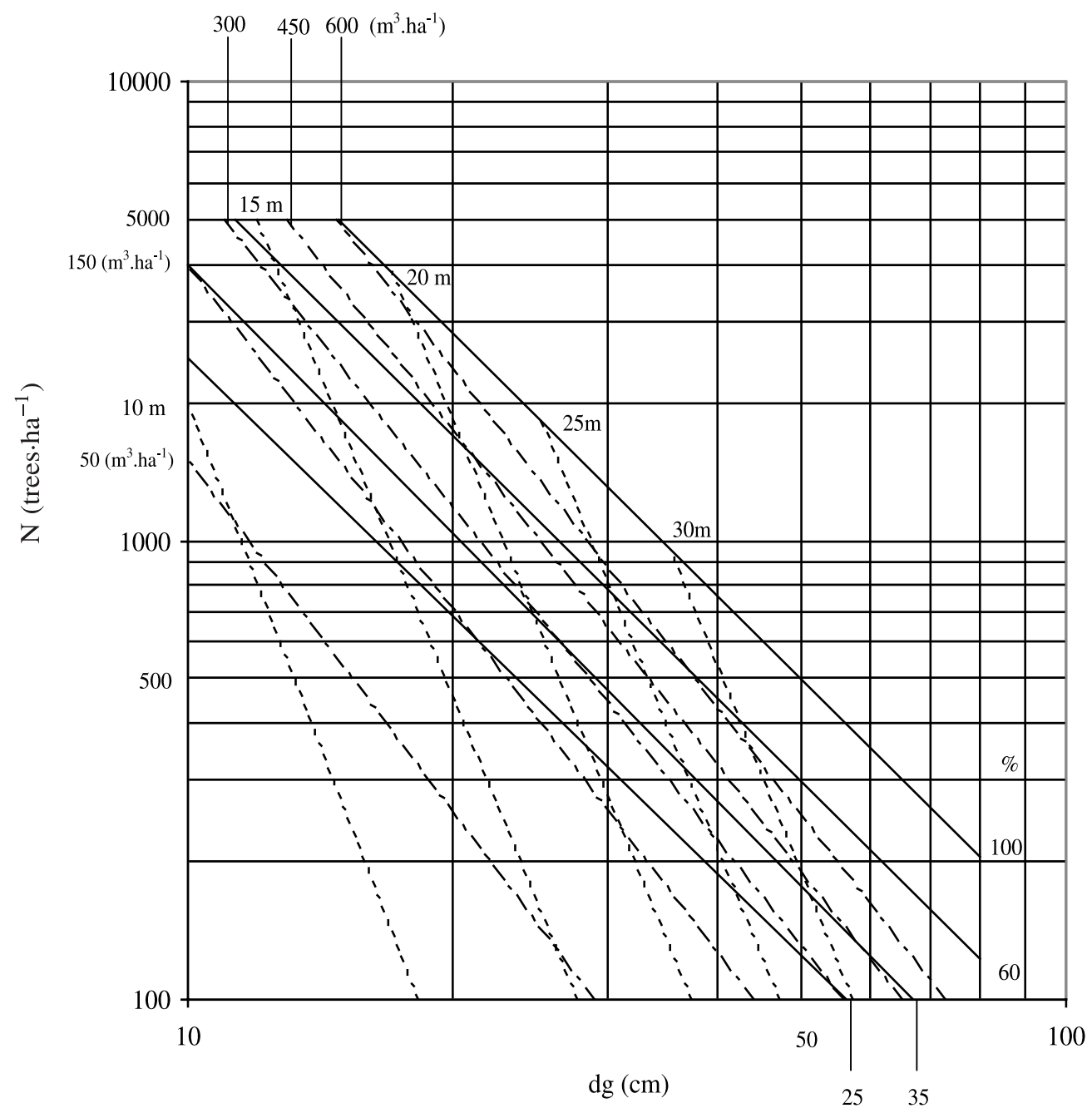

Figure 2. Comprehensive stand density diagram for Pinus pinaster in Portugal. - - - $h d$ isolines, $-\bullet-V$ isolines, ----- density lines.

Table II. $N\left(\right.$ trees $\left.\cdot \mathrm{ha}^{-1}\right)$ for different spacings.

\begin{tabular}{lcccc}
\hline \multicolumn{4}{c}{ Spacing $(\mathrm{m}, \%)$} \\
\cline { 2 - 5 }$(b h$ & Maximum $^{1}$ & $1.5 \times 1.0$ & $2.0 \times 1.5$ & $2.0 \times 2.0$ \\
$(\mathrm{~cm})$ & $(100)$ & $(63)$ & $(32)$ & $(24)$ \\
\hline 10 & 10572 & 6666 & 3333 & 2500 \\
15 & 4899 & 3089 & 1545 & 1159 \\
20 & 2839 & 1790 & 895 & 671 \\
25 & 1859 & 1172 & 586 & 440 \\
30 & 1315 & 829 & 415 & 311 \\
35 & 982 & 619 & 310 & 232 \\
40 & 762 & 481 & 240 & 180 \\
45 & 610 & 384 & 192 & 144 \\
50 & 499 & 315 & 157 & 118 \\
\hline
\end{tabular}

${ }^{1}$ Computed by equation (13).
In developing the associated relationships for the stand density diagram, the models of Dean and Baldwin [5] and Kumar et al. [18] were tested. Kumar et al.'s [18] models present some pitfalls in the independent variables selection (Eq. (10)) and, according to Décourt [7], in the model development assumptions (Eq. (11)), leading respectively, to improper model behavior and/or biased model results. The different models fitting and adjustment criteria, on the 274 inventory plots, led to the selection Dean and Baldwin's [5] models:

$$
\begin{gathered}
V=0.063 d g^{2.096}\left(\frac{N}{1000}\right)^{0.978} h d^{0.668} \\
d g=45.851 V^{0.365} N^{-0.407}
\end{gathered}
$$

Equation (17), relating $d g, N$ and $h d$ with $V$, explained $99.8 \%$ of the variation of the observed volume with a $s_{y x}$ of $4.99 \mathrm{~m}^{3} \cdot \mathrm{ha}^{-1}$. Equation (18), relating $V$ and $N$ with $d g$, explained $99.1 \%$ of the total variation of $d g$ with a $s_{y x}$ of $0.89 \mathrm{~cm}$. Residual analysis 


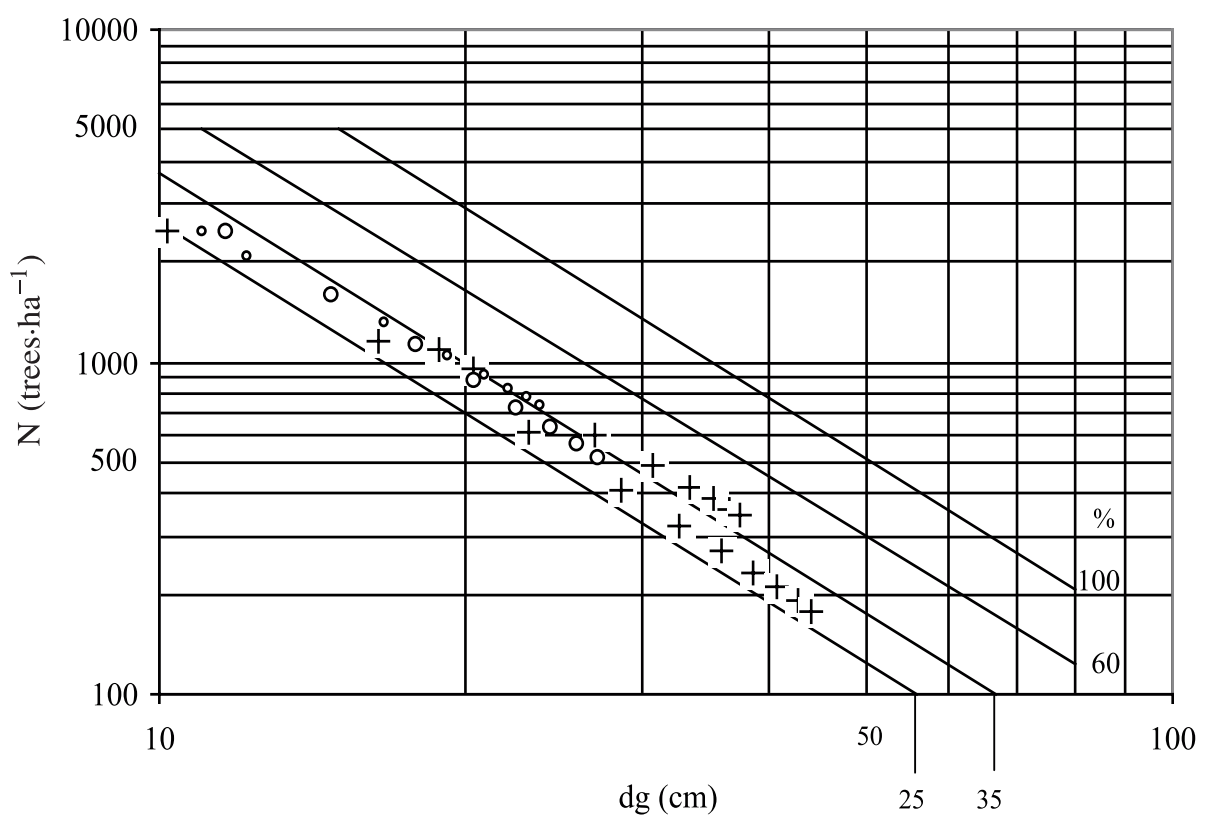

Figure 3. Yield models evolution in the stand density diagram. + better sites, o poorer sites.

did not show any apparent trend and all the models coefficients were significant.

Solving equation (18) for the $V$ term, substituting it into equation (17) and solving for $h d$ yielded:

$$
h d=0.236 d g^{0.962} N^{0.207} .
$$

Equations (17) and (19) enable drawing the $V$ and $h d$ isolines, respectively, onto the stand density diagram for Pinus pinaster in Portugal (Fig. 2). $V$ was set at 5 levels: 50, 150, 300, 450 and $600 \mathrm{~m}^{3} \cdot \mathrm{ha}^{-1}$ and $h d$ was also set at 5 levels: 10, 15, 20, 25 and $30 \mathrm{~m}$.

The approximate stand age can be obtained from site index curves, as long as site index $(S I)$ information is available. Using a Pinus pinaster site index model [8], for an index age of 50 years and solving for $t$, yielded:

$$
t=\frac{9.235}{0.185+\log _{10}(S I / h d)} .
$$

\section{DISCUSSION}

\subsection{Management applications}

Oliveira [28], Hall and Martins [13], Moreira and Fonseca [25] and Páscoa [30] developed growth and yield models for Pinus pinaster in Portugal. The first three are average tree models and the fourth is a diameter distribution model [31], using the Weibull probability density function.

Figure 3 shows the main stand evolution for better (+) and poorer (o) sites from the first two models. These trends follow closely the interval between the $35 \%$ and $25 \%$ lines (i.e., the lower limit line for the optimum growth-density zone and the crown closure line), suggesting that the proposed diagram mimics quite well the main silvicultural systems for the species in Portugal.

Scheduling of management regimes is the most important use for the diagram. Three alternatives are discussed: (a) an unthinned regime, (b) a commercial thinning regime, (c) a precommercial thinning regime (Fig. 4). The first regime corresponds to the research control treatment and is practiced by the absentee landowners, yielding high mortality and low timber value. The second regime is focused on maximizing the stand volume or the tree volume. The third regime is an unusual and extreme situation, but presented in this study mostly for comparison purposes.

Let us consider, for example, an initial stand, in a $24 \mathrm{~m}$ site quality class, at an index age of 50 years, with $10 \mathrm{~cm}$ for $d g$ and 2500 for $N$ and, for the different management alternatives, a target $d g$ of $30 \mathrm{~cm}$. Estimates of growth and age can be included in the analysis [23], using the diagram $h d$ and $V$ lines, and site index curves, respectively.

In the unthinned alternative (Fig. 4, a), $d g$ increases with almost no reduction in $N$, until the stands reaches the self-thinning zone (the $60 \%$ line). Further increase in size occurs with decrease in $N$ and the stand path equilibrium follows the $60 \%$ line (Fig. 4). Mortality starts around 29 years, at an estimated $d g$ of $16.3 \mathrm{~cm}$ and an estimated $h d$ of $17.5 \mathrm{~m}$, involving 1771 trees $\cdot \mathrm{ha}^{-1}$ and yielding $456 \mathrm{~m}^{3} \cdot \mathrm{ha}^{-1}$. When $d g$ reaches the target value $(30 \mathrm{~cm})$ the $h d$ estimate is $24.7 \mathrm{~m}$, the final harvest age is 54 years with a MAI of $18.4 \mathrm{~m}^{3} \cdot \mathrm{ha}^{-1} \cdot \mathrm{yr}^{-1}$ (Tab. III).

In the commercial thinning alternative (Fig. $4, \mathrm{~b}$ ), the stand path (before and after thinnings) should be between the $60 \%$ 


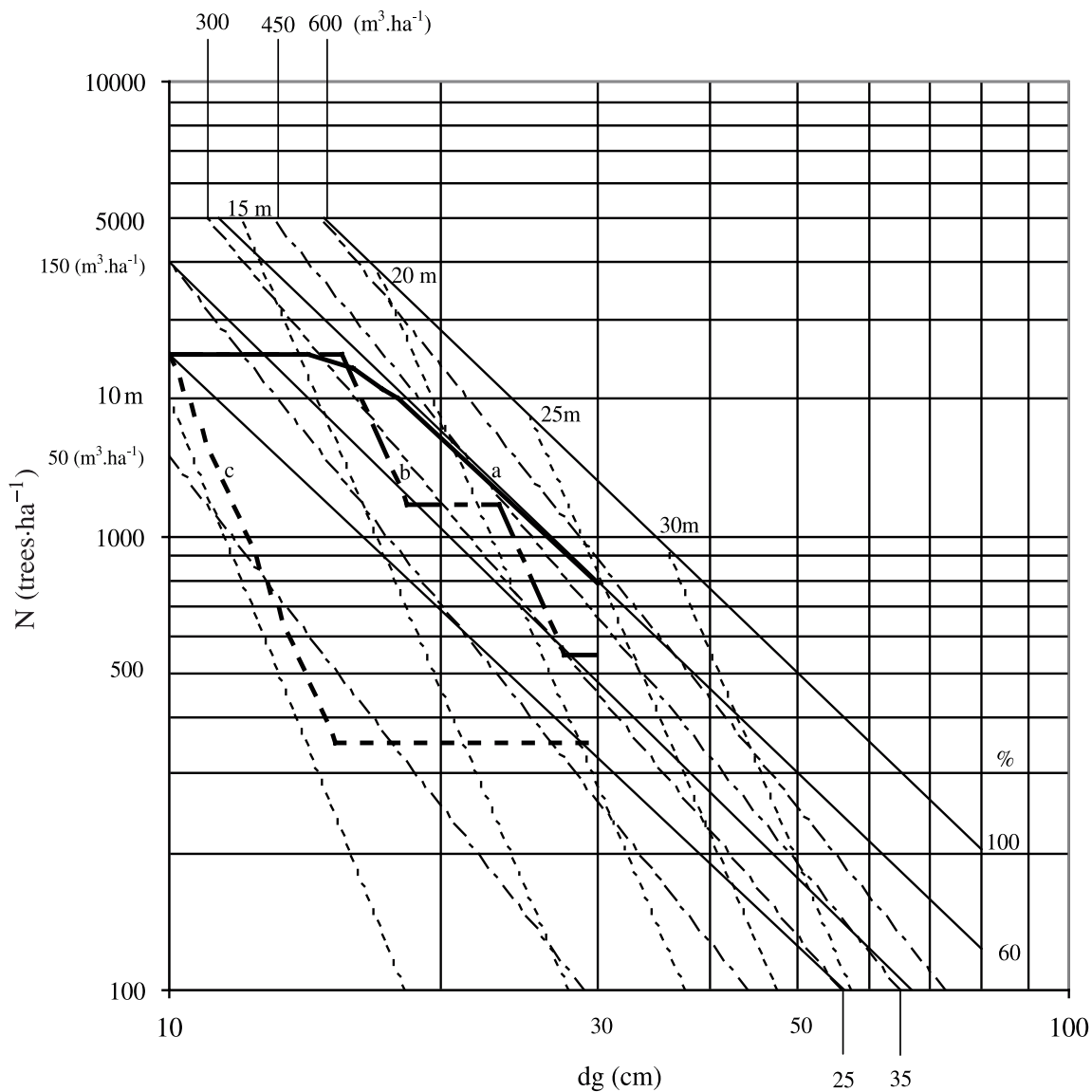

Figure 4. Alternative density management regimes. a, unthinned; b, commercial; c, precommercial.

Table III. Comparison of three alternative management regimes. Mean Annual Increment $\left(\mathrm{m}^{3} \cdot \mathrm{ha}^{-1} \cdot \mathrm{yr}^{-1}\right)$ is based on age at final harvest and includes yields from mortality, precommercial thinning (PCT), commercial thinnings (CT) and final harvest.

\begin{tabular}{|c|c|c|c|c|c|c|c|}
\hline & \multirow{2}{*}{$\begin{array}{c}t \\
\text { (years) }\end{array}$} & \multirow{2}{*}{$\begin{array}{l}h d \\
\text { (m) }\end{array}$} & \multicolumn{2}{|c|}{$N\left(\right.$ trees $\cdot$ ha $\left.^{-1}\right)$} & \multicolumn{2}{|c|}{$d g(\mathrm{~cm})$} & \multirow{2}{*}{$\begin{array}{c}V \\
\left(\mathrm{~m}^{3} \cdot \mathrm{ha}^{-1}\right)\end{array}$} \\
\hline & & & before & after & before & after & \\
\hline \multicolumn{8}{|c|}{ Unthinned } \\
\hline Mortality & 29 & 17.5 & 2500 & 789 & 16.3 & 30.0 & 456 \\
\hline Final harvest & 54 & 24.7 & 789 & & 30.0 & & 536 \\
\hline Total yield & & & & & & & 992 \\
\hline MAI & & & & & & & 18.4 \\
\hline \multicolumn{8}{|c|}{ Commercial } \\
\hline CT 1 & 27 & 16.7 & 2500 & 1166 & 15.6 & 18.4 & 108 \\
\hline CT 2 & 38 & 21.0 & 1166 & 544 & 23.3 & 27.5 & 138 \\
\hline Final harvest & 45 & 22.9 & 544 & & 30.0 & & 354 \\
\hline Total yield & & & & & & & 600 \\
\hline MAI & & & & & & & 13.3 \\
\hline \multicolumn{8}{|c|}{ Precommercial } \\
\hline CT & 18 & 10.9 & 2500 & 350 & 10.0 & 15.3 & 62 \\
\hline Final harvest & 38 & 20.9 & 350 & & 30.0 & & 216 \\
\hline Total yield & & & & & & & 278 \\
\hline MAI & & & & & & & 7.3 \\
\hline
\end{tabular}


and $35 \%$ lines. Although mortality may occur after stand establishment and before its entry in the eminent competition mortality zone (above the $60 \%$ line) and is, mostly, density independent and difficult to predict [10], the probability of occurrence strongly increases in the $60 \%$ line neighborhood. We therefore consider the simplifying assumption that no natural mortality occurs below the $55 \%$ line.

Keeping the stand path in the 35 to $55 \%$ interval means that the site is fully used and the self-thinning is probably avoided. Total stand volume harvested is maximized, although tree growth is not at its maximum [36], because it is balanced by the high number of residual trees. In this study, the thinning type is from below and to account for the $d g$ increase with this thinning type, these segments are drawn parallel with the nearest $h d$ line, on the assumption that this thinning type has no effect on the $h d$ growth [5]. When $d g$ reaches the target value $(30 \mathrm{~cm})$ the $h d$ estimate is $22.9 \mathrm{~m}$, the final harvest age is 45 years and the MAI is $13.3 \mathrm{~m}^{3} \cdot \mathrm{ha}^{-1} \cdot \mathrm{yr}^{-1}$ (Tab. III).

In the precommercial thinning alternative (Fig. 4, c), a single heavy precommercial thinning is used to set up the final $N$ harvest at 350 , cutting 2150 trees $\cdot \mathrm{ha}^{-1}$. The $d g$ after thinning is $15.3 \mathrm{~cm}$ and when it reaches the target value $(30 \mathrm{~cm})$ the $h d$ estimate is $20.9 \mathrm{~m}$, the final harvest age is 38 years and the MAI is $7.3 \mathrm{~m}^{3} \cdot \mathrm{ha}^{-1} \cdot \mathrm{yr}^{-1}$ (Tab. III).

Mortality is observed only in the unthinned regime, corresponding to a $41 \%$ loss in total yield. The target $d g(30 \mathrm{~cm})$ is reached, for the three regimes, at 54, 45 and 38 years, respectively, meaning that the average $d g$ growth is $0.55,0.66$ and $0.79 \mathrm{~cm} \cdot \mathrm{yr}^{-1}$ for the final residual trees. The annual tree volume growth, at the final harvest age is, respectively, 0.009, 0.020 and $0.026 \mathrm{~m}^{3} \cdot \mathrm{yr}^{-1}$ and this expected tree growth increase, as the thinnings get heavier, does not offset the decrease in the residual number of trees, resulting in a decreasing trend in final total yield among the management regimes, from unthinned $\left(992 \mathrm{~m}^{3} \cdot \mathrm{ha}^{-1}\right)$ to commercially thinned $\left(600 \mathrm{~m}^{3} \cdot \mathrm{ha}^{-1}\right)$ and precommercially thinned $\left(278 \mathrm{~m}^{3} \cdot \mathrm{ha}^{-1}\right)$.

The individual tree volume, at the final harvest age, is 0.68 , 0.65 and $0.61 \mathrm{~m}^{3}$, respectively. The unthinned regime individual tree volume $\left(0.68 \mathrm{~m}^{3}\right)$, at the current tree volume rates, is reached by the commercial regime after 2 additional years (at 47 years), 7 years before the unthinned regime and by the precommercial regime after 3 additional years (at 41 years), 13 years before the unthinned regime.

Newton [26] and Doruska and Nolen [9] pointed out that density management diagrams are often difficult to read and subject to user-induced graphical interpolation error. Following these authors' suggestion an algorithm version and a spreadsheet application was developed enhancing the utility of the stand density diagram for Pinus pinaster in Portugal. Both algorithm and spreadsheet are available by the first author upon request.

\section{CONCLUSIONS}

This study presents a comprehensive approach for Pinus pinaster even-aged stand management in Portugal, adapted to the great majority of situations observed in the country, based on the 1998 National Forest Inventory data.
The self-thinning allometric model is a linear limiting relationship, between plant density and average plant size. Its development requires upper boundary plots selection and the statistical upper confidence interval calculation for the intercept term. The self-thinning allometric model slope coefficient $(-1.897)$ lies within the interval observed by other authors.

The upper and lower limits for the optimum growth-density interval, as well as the crown closure line require attention. In this study, square spacing and $10 \mathrm{~cm}$ reference $d b h$ were selected to calculate these limits and line, and the resulting values, respectively 63, 32 and $24 \%$, are also within the interval observed by other authors.

The associated relationships developed in this study allow evaluation of thinning regimes in terms of age, height and volume (Fig. 2). Age is an implicit variable, which can be calculated from site index curve equations if site index information is available. Compared to the unthinned regime, a target $d g$ $(30 \mathrm{~cm})$ was reached between 9 (commercial regime) and 16 (precommercial regime) years earlier, but for considerably lower remaining trees $\cdot$ ha $^{-1}, 544$ (less 245) and 350 (less 439), respectively. Compared to the unthinned regime, total yield for the commercial and precommercial regimes are, respectively, $60 \%$ and $28 \%$ lower. However, the commercial regime performs better than the unthinned regime, which contains $456 \mathrm{~m}^{3} \cdot \mathrm{ha}^{-1}$ of mortality. On the other hand, the precommercial regime clearly underutilizes the site (Tab. III).

This study results confirms the known effects of thinning regimes intensity on tree and stand variables development. The heavier the thinnings regimes, the higher the tree variables (average $d g$ and tree volume growth) and the lower the stand variables (residual final trees and total yield) become.

Acknowledgements: The authors acknowledge the 1998 National Forest Inventory data availability, provided by Direcção General das Florestas, Lisboa.

\section{REFERENCES}

[1] Alboreca A.R., Gonzalez G.M., El Pino Sylvestris en la Sierra de Guadarrama, MAPA, Madrid, 1996.

[2] Broad L.R., Allometry and growth, For. Sci. 44 (1998) 458-464.

[3] Cao Q.V., Dean T.J., Baldwin V.C., Modelling the size-density relationship in direct-seeded slash pine stands, For. Sci. 46 (2000) 317-321.

[4] Clutter J., Fortson J., Pienaar L., Brister G., Bailey R., Timber management: A quantitative approach, John Wiley and Sons, New York, 1983

[5] Dean T.J., Baldwin V.C., Using a density-management diagram to develop thinning schedules for Loblolly pine plantations, USDA For. Serv. Res. Pap. SO-275, 1993.

[6] Dean T.J., Jokela E.J., A density management diagram for slash pine plantations in the lower Coastal Plain, South. J. Appl. For. 16 (1992) 178-185.

[7] Décourt N., Remarque sur une relation dendrométrique inattendue Conséquences méthodologiques pour la construction des tables de production, Ann. Sci. For. 31 (1974) 47-55.

[8] DGF, Inventário Florestal Nacional. Portugal Continental, MAP, Lisboa, 2001.

[9] Doruska P.F., Nolen W.R., Use of stand density index to schedule thinnings in Loblolly pine plantations: a spreadsheet approach, South. J. Appl. For. 23 (1999) 21-29. 
[10] Drew T.J., Flewelling J.W., Some recent Japanese theories of yield density relationships and their applications to Monterey pine plantations, For. Sci. 23 (1977) 517-534.

[11] Drew T.J., Flewelling J.W., Stand density management: an alternative approach and its application to Douglas-fir plantations, For. Sci. 25 (1979) 518-532.

[12] Flewelling J.W., Drew T.J., A stand density management diagram for lodgepole pine, in: Baumgarter D.M., Krebill R.G., Arnott J.T., Weetman G.F. (Eds.), Lodgepole pine: the species and its management, Coop. Ext., Washington State Univ., Pullman, 1985, pp. 239244.

[13] Hall A., Martins L., A Previsão do Volume do Povoamento Total. Um Estudo para o Pinheiro Bravo, SPCF, I Congresso Florestal Nacional, Comunicações, Lisboa, 1986, pp. 71-77.

[14] Harper J.L., Population biology of plants, Academic Press, New York, 1977.

[15] Gadow K., Observations on self-thinning in pine plantations, S. Afr. J. Sci. 82 (1986) 364-368.

[16] Hozumi K., Shinozak K., Tadaky Y., Studies on the frequency distribution of the weight of individual trees in a forest stand. A new approach towards the analysis of the distribution function and the 3/2th power distribution, J. Ecol. 18 (1968) 10-20.

[17] Keeney R., Raiffa H., Decisions with multiple objectives: preferences and value tradeoffs, John Wiley and Sons, New York, 1976.

[18] Kumar B.M., Long J., Kumar P., A density management diagram for teak plantations of Kerala in Peninsular India, For. Ecol. Manage. 74 (1995) 125-131.

[19] Langsaeter A., Om tynning I enaldret gran-og furuskog. Meddel. f. d., Nor. Skogforsoksvesen 8 (1941) 131-216.

[20] Lloyd F.T., Harms W.R., An individual stand growth model for mean plant size based on the rule of self-thinning, Ann. Bot. 57 (1986) 681-688.

[21] Long J., A practical approach to density management, For. Chron. 61 (1985) 23-27.

[22] Luis J.F.S., Bento J.S., Oliveira A.C., A Relação Alométrica na Condução de Povoamentos Florestais. O caso do Pinus pinaster em Portugal, in: Páscoa F., Martinho A., Santos H., Ribeiro T. (Eds.), Pinhal Bravo, Material Lenhoso e Resina, Comunicações do Encontro da SPCF, ESAC, Coimbra, 1991, pp. 149-157.

[23] McCarter J.B., Long J., A Lodgepole pine density management diagram, West. J. Appl. For. 1 (1986) 6-11.

[24] Moller C., The effect of thinning, age, and site on foliage, increment, and loss of dry matter, J. For. 45 (1947) 393-404.

[25] Moreira A.M., Fonseca T.F., Tabela de Produção para o Pinhal do Vale do Tâmega, Silva Lusitana 10 (2002) 63-71.
[26] Newton F.P., Stand density management diagrams: Review of their development and utility in stand-level management planning, For. Ecol. Manage. 98 (1997) 251-265.

[27] Newton F.P., Weetman G.F., Stand density diagrams for managed black spruce stands, For. Chron. 70 (1994) 65-74.

[28] Oliveira A.C., Tabela de Produção Geral para o Pinheiro Bravo das Regiões Montanas e Submontanas, DGF, CEF, Lisboa, 1985.

[29] Palahí M., Pukkala T., Optimising the management of Scots pine (Pinus sylvestris L.) stands in Spain based on individual-tree models, Ann. For. Sci. 60 (2003) 105-114.

[30] Páscoa F., Estrutura Crescimento e Produção em Povoamentos de Pinheiro Bravo. Um Modelo de Simulação, Tese de Doutoramento, ISA, UTL, Lisboa, 1987.

[31] Porté A., Bartelink H.H., Modelling mixed forest growth: a review of models for forest manage. For. Ecol. Manage. 150 (2002) 141188.

[32] Prodan M., Forest biometrics, Pergamon Press, Oxford, 1968.

[33] Reineke L.H., Perfecting a stand-density index for even aged forests, J. Agric. Res. 46 (1933) 627-639.

[34] Smith N.J., Hann D.W., A growth model based on the self-thinning rule, Can. J. For. Res. 16 (1986) 330-334.

[35] Smith D.M., Larson B.C., Kelty M.J., Ashton P., The Practice of silviculture. Applied forest ecology, John Wiley and Sons, New York, 1996.

[36] Staebler G.R., Optimum levels of growing stock for managed stands, Proceedings SAF meeting 23 (1959) 110-113.

[37] Wetsbody M., Howell J., Influence of population structure on selfthinning of plant populations, J. Ecol. 74 (1986) 343-359.

[38] White J., The allometric interpretation of the self-thinning rule, J. Theor. Biol. 89 (1981) 475-500.

[39] White J., Harper J., Correlated changes in plant size and number in plant populations, J. Ecol. 63 (1970) 467-485.

[40] Wilson F.G., Numerical expression of stocking in terms of height, J. For. 44 (1946) 758-761.

[41]Wilson F.G., Thinning as an orderly discipline: A graphic spacing schedule for red pine, J. For. 77 (1979) 483-486.

[42] Xue L., Ogawa K., Hagihara A., Liang S., Bai J., Self-thinning exponents based on the allometric model in Chinese pine (Pinus tabulaeformis Carr.) and Prince Rupprecht's larch (Larix principisrupprechtti Mayr) stands, For. Ecol. Manage. 117 (1999) 87-93.

[43] Yoda K., Kira T., Ogawa H., Hozumi K., Self-thinning in overcrowded pure stands under cultivated and natural conditions, J. Biol. 14 (1963) 107-129.

[44] Zeide B., Analysis of the $3 / 2$ power law of self-thinning, For. Sci. 33 (1987) 517-537. 